Creative Commons User License: CC BY-NC-ND

Abstracted by: EBSCOhost, Electronic Journals Service (EJS),

Google Scholar, Journal Seek, Scientific Commons,

Food and Agricultural Organization (FAO), CABI and Scopus

http://eoi.citefactor.org/10.11226/v23i4
Journal of Agricultural Extension

Vol. 24 (1) January, 2020

ISSN(e): 24086851; ISSN(Print); 1119944X

http://journal.aesonnigeria.org

http://www.ajol.info/index.php/jae

Email: editorinchief@aesonnigeria.org

\title{
Adoption of Improved Maize Varieties in Northern Guinea Savannah of Borno State, Nigeria
}

https://dx.doi.org/10.4314/jae.v24i1.4

\section{Kadafur, Ibrahim Mohammed}

Department of Socio-economic, International Institute of Tropical Agriculture, Kano, Nigeria.

E-mail: I.Kadafur@cgiar.org, Phone Number: +2348065728875

\section{Idrisa, Yusuf Lawal}

Department of Agricultural Extension Services, University of Maiduguri, Nigeria.

E-mail: yuzaat696@gmail.com, Phone Number: +2348030605207

\section{Shehu, Abbas}

Department of Agricultural Economics and Extension, Abubakar Tafawa Balewa University, Bauchi, Nigeria.

E-mail: abbasecons@gmail.com, Phone Number:+2348034107403

Correspondence: abbasecons@gmail.com +2348034107403

\section{Abstract}

This study examined the adoption of improved maize varieties in northern Guinea Savanna of Borno State. Primary data were collected by using structured interview schedule. Two hundred maize farmers were systematically selected from. Percentage and logit were used for data analyses. Overall adoption rate was $89.0 \%$. Coefficient of socio-economic and institutional factors such as extension contact (0.0360), farm size (0.2319), education level (0.0460), access to credit (0.6363) and age (0.7619) were found to be significant $(P \leq 0.01)$ and positively influencing adoption of improved maize varieties. Household size (0.2708) and income level (0.3285) were also significant $(P \leq 0.05)$ and positively related to likelihood of adoption of improved maize varieties. Non-availability of technology (99\%), high cost of technology (92\%) and high cost of labour (88\%) were the major constraining factors to adoption of improved maize varieties. Community seed production should be encouraged and promoted to facilitate easy access to improved seeds by farmers. The extension system should be strengthened, a policy, which provides adequately trained and equipped extension workers for disseminating extension messages to farmers, re-strengthening of community based organizations and seed companies to introduce labour saving tools like planters and harvesters etc.

Keywords: Adoption; improved maize; guinea savannah

\section{Introduction}

In Borno State, maize is produced by both small and large-scale farmers in the Guinea Savannas where it is widely consumed as a staple food by poor rural and urban households. Dry maize flour is used in preparing food (Tuwo) which is commonly consumed among households, green fresh maize is boiled or roasted and hawked by women and children, providing a livelihood for many poor households. Maize is also processed industrially for 
Creative Commons User License: CC BY-NC-ND

Abstracted by: EBSCOhost, Electronic Journals Service (EJS),

Google Scholar, Journal Seek, Scientific Commons,

Food and Agricultural Organization (FAO), CABI and Scopus
Journal of Agricultural Extension

Vol. 24 (1) January, 2020

ISSN(e): 24086851; ISSN(Print); 1119944X

http://journal.aesonnigeria.org

http://www.ajol.info/index.php/iae

Email: editorinchief@aesonnigeria.org

flour, animal feeds, biscuits, beverages and beer and in these forms is consumed widely across Nigeria (Benjamin, 2013).

Maize production was initially concentrated in the southern part of Nigeria, along the rainforest, extending to the derived savannah, where the bi-modal rainfall pattern permits the raising of two crops per year. However, in recent years the expansion of the crop was limited by lack of improved varieties that can withstand climatic and soil factors. Research to improve the existing maize varieties, with a view to increase production, were initiated in different research institutes in Nigeria such as the Institute for Agricultural Research (IAR) at Ahmadu Bello University (ABU) Zaria and International Institute for Tropical Agriculture (IITA) Ibadan. These Improved Maize Varieties were Sammaz 15, Sammaz 16, Sammaz 27 and Corn 5 DT, were promoted by a project Promoting Sustainable Agriculture in Borno State (PROSAB) and Borno State Agricultural Development Program (BOSADP)

Until recently, most of the farmers producing maize relied on traditional technology with low use of improved inputs. The country provides an interesting case study because the importance of maize as an income-generating food staple has been increasing steadily during the last two decades. National average grain yields have increased from $1.13 \mathrm{t} / \mathrm{ha}$ in 1990 to about 1.85 t/ha in 2014 and Borno included (FAOSTAT 2016). The int=roduction of improved agricultural technologies to farmers will help manage the constraints facing maize farmers. Doss (2013) opined that adoption of improved technologies is an important means to increase the productivity of smallholder farmers in Africa, thereby fostering economic growth and improve wellbeing of millions of the poor households, it is important to understand the factors which determine the likelihood and rate of adoption of improved technologies.

Maize is an important crop in Borno State. Its production is however, affected by many constraints. These include drought, poor soil fertility and the parasitic weed (Striga harmontheca). In an attempt to ensure continued maize production in the face of these challenges, improved maize varieties that have the capacity to withstand such challenges were developed and introduced to Borno State through PROSAB project. With the existence of community seed producers and the increase in market for crop commodities like maize, adoption of maize varieties may have changed.

Adoption is defined as the stage a respondent decides that the improved maize variety is good enough for full scale and continued use. While Adopter can be defined as any farmer who allocated 30\% and above of his land to Improved Maize Varieties. It would be useful for researchers to use similar definitions, where appropriate; at a minimum, variables should be clearly defined in ways that facilitate comparisons.

Adoption rate is the relative speed with which an innovation is adopted over time and space by members of a social system. The rate of adoption is usually measured by the length of time required for a certain percentage of members of a system to adopt an innovation. The current study focuses on the rate of adoption and the factors affecting it. Adoption is usually expressed as percentages. Several studies have been carried out to determine rates of 
Creative Commons User License: CC BY-NC-ND

Abstracted by: EBSCOhost, Electronic Journals Service (EJS),

Google Scholar, Journal Seek, Scientific Commons,

Food and Agricultural Organization (FAO), CABI and Scopus

http://eoi.citefactor.org/10.11226/v23i4
Journal of Agricultural Extension

Vol. 24 (1) January, 2020

ISSN(e): 24086851; ISSN(Print); 1119944 X

http://journal.aesonnigeria.org

http://www.ajol.info/index.php/jae

Email: editorinchief@aesonnigeria.org

adoption of maize technologies in Nigeria and Sub-Saharan Africa at large. Cavane, E. (2016) found that the adoption of improved seed and chemical fertilizers to boost production is still limited in Northern Mozambique.

\section{Purpose of study}

The main objective of the study was to examine the factors affecting adoption of improved maize varieties in Northern Guinea Savannah of Borno State. The specific objectives were to;

i. determine the adoption rate of improved maize varieties;

ii. examine the factors affecting likelihood of adoption of improved maize varieties; and

iii. identify the constraints associated with the adoption of improved maize varieties

\section{Methodology}

The study was carried out in the northern guinea savannah of Borno State., It consist of three Local Government Areas (Biu, Hawul and Kwayakusar). located between Latitude $10^{\circ}$ and $12^{\circ}$ north of the Equator and Longitude $11^{\circ} 30$ and $14^{\circ}$ east.

Multi-stage sampling procedure was used to select the population for the study. In the first stage, the three Local Government Areas Biu, Kwayakusar and Hawul of the Northern Guinea Savannah (NGS) ecological zone of the state were selected for the study, this was due to the fact that they are the major Maize producing areas and hence used for the intervention in the state. In the second stage, three districts Mirnga, Biu North and East, Kwayakusar,Wandali, Kwayabura, Sakwa and Kidang were randomly selected from each Local Government Areas. In the third stage one community is randomly selected from each district, giving a total of nine (9) communities. In the fourth stage, a list of maize farmers was obtained from Borno State Agricultural Program (BOSADP) office. From which fifteen percent $(15 \%)$ of total population of maize farmers were drawn using systematic random sampling giving a total of two hundred and fifty (250) respondents.

The analytical techniques used to analyze the data for this study was descriptive and inferential statistics. These include percentages and Logit model.

Table 1: Selected respondents based on selected study communities

\begin{tabular}{ccl}
\hline Community & $\begin{array}{l}\text { Proportion } \\
\text { used }\end{array}$ & $\begin{array}{l}\text { Number of } \\
\text { registered farmers }\end{array}$ \\
\hline Mirnga & 40 & 266 \\
Mainahari & 25 & 166 \\
Tum & 22 & 147 \\
Jalingo & 20 & 133 \\
Kinging & 19 & 126 \\
Kwayabura & 28 & 186 \\
Wandali & 31 & 206 \\
Kwayakusar & 40 & 266 \\
Ngabu & 25 & 166
\end{tabular}


Creative Commons User License: CC BY-NC-ND

Abstracted by: EBSCOhost, Electronic Journals Service (EJS),

Google Scholar, Journal Seek, Scientific Commons,

Food and Agricultural Organization (FAO), CABI and Scopus

http://eoi.citefactor.org/10.11226/v23i4
Journal of Agricultural Extension

Vol. 24 (1) January, 2020

ISSN(e): 24086851; ISSN(Print); 1119944 X

http://journal.aesonnigeria.org

http://www.ajol.info/index.php/iae

Email: editorinchief@aesonnigeria.org

\section{Total}

250

1667

\section{Logit Model Specification}

This model was used to identify the factors that influence the likelihood of adoption of improved maize varieties by farmers. Earlier studies (Idrisa et al ;2010) used Logit model to identify factors affecting the likelihood of adoption of improved technologies.

The explicit form of the Logit model is presented as follows:

$$
Y_{i}=b_{0}+b_{1} X_{1}+b_{2} X_{2}+b_{3} X_{3}+b_{4} X_{4}+b_{5} X_{5}+b_{6} X_{6}+b_{7} X_{7}+b_{8} X_{8}+b_{9} X_{9}+b_{10} X_{10}+b_{11} X_{11}+b_{12} X_{12}+u
$$

Where,

$Y_{i}$ (adoption) $=$ observed response for the ith respondent, which is in binary form: $Y_{i}=0$ non adopters and $Y_{i}=1$ for adopters.

$Y_{i}=1$ (only farmers who planted at least $30 \%$ of their total land area to improved maize variety.)

$Y_{i}=0$ ( for any farmer that has less than $30 \%$ of their farm under improved maize varieties.)

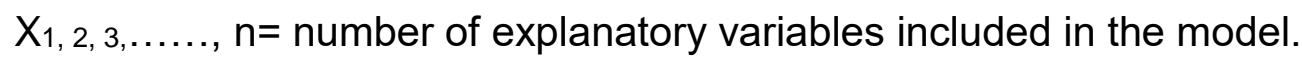

The explanatory variables included in the model include:

$X_{1}=\operatorname{Sex}$ (Dummy) ( $D=1$ if male and 0 otherwise)

$\mathrm{X}_{2}=$ Education (years of formal education)

$\mathrm{X} 3=$ Household size (Number of persons)

$\mathrm{X}_{4}=$ Income $(\mathrm{N})$

$\mathrm{X}_{5}=$ Farm Size $(\mathrm{ha})$

$\mathrm{X}_{6}=$ Age $(\mathrm{yrs})$

$\mathrm{X}_{7}=$ Utilization of Maize at household level, Dummy variable $(1,0)(\mathrm{D}=1$ if used in the $\mathrm{HH}$ and 0 otherwise)

$X_{8}=$ Maturity period (measured in days improved maize spend on field before maturity)

$\mathrm{X}_{9}=$ Extension contact (measured in number of visits by extension agents to farmers).

$\mathrm{X}_{10}=$ Distance to market $(\mathrm{Km})$

$X_{11}=$ Accessibility to credit, Dummy variable $(1,0)(D=1$ if accessed and 0 otherwise $)$

$\mathrm{X}_{12}=$ Distance to source of technology (measured in Kilometers).

$\mathrm{U}=$ error term

\section{Results and Discussion}

Factors Influencing the Likelihood of Adoption of Improved Maize Varieties 
Creative Commons User License: CC BY-NC-ND

Abstracted by: EBSCOhost, Electronic Journals Service (EJS),

Google Scholar, Journal Seek, Scientific Commons,

Food and Agricultural Organization (FAO), CABI and Scopus
Journal of Agricultural Extension

Vol. 24 (1) January, 2020

ISSN(e): 24086851; ISSN(Print); 1119944X

http://journal.aesonnigeria.org

http://www.ajol.info/index.php/iae

Email: editorinchief@aesonnigeria.org

http://eoi.citefactor.org/10.11226/v23i4

Table 2 reveals that the coefficient of extension contact was found to be positive $\mathbf{B}=0.0360$ $(P \leq 0.01)$ and significantly related to famers decision to adopt improved maize varieties in the study area. This result implies that respondents with high number of extension contact have greater chance of adopting the technologies. The coefficient of farm size was found to be positive $B=0.2319(P \leq 0.01)$ and significantly related to the probability of adoption of improved maize variety as a production technology in the study area. This implies that the bigger the farm size, the greater the chance of adoption of improved maize varieties. Large farm holding enables farmers practice new technologies without risking his/her farm investment. Kamara, A. Y., Kamai, N., \& Kanampiu, F. (2018) reported that farmers with small farm sizes utilize less improved production information.

The coefficient of education level was found to be positive $=0.0460(P \leq 0.01)$ and significantly related to the likelihood of adopting improved maize variety as a production technology in the study area. This implies the higher the years spent on formal education, the greater the chance of adopting improved maize variety as a production technology among farmers in the study area. This could be as a result of access to information and awareness brought about by education. People with higher levels of education have higher capacity to adopt innovations. This agrees with earlier studies (Kamara, A. Y., et. al. 2018) that level of education of farmers had significant relationship with adoption of technology by farmers. The coefficient of access to credit was found to be positive $B=0.6363$ ( $P \leq 0.01$ ) and significantly related to the probability of improved maize variety adoption in the study area. This implies that farmers who had access to credit had greater chance of adopting improved maize varieties. This is in line with the assertion of (Idrisa et al, 2012) that accessibility to credit reduces the level of risk associated with adoption of technologies on the side of a farmer, thereby increasing the likelihood of adoption. The coefficient of household size was also found to be positive $B=0.2708$ ( $P \leq 0.05)$ and significantly related to the likelihood of adoption of improved maize variety as a production technology in the study area. This result implies that household with large membership had greater chance of adoption of improved maize variety as production technology compared to households with fewer members. Farming activities in developing countries are not mechanized. Most often operations are done manually. This will require family labour, given that the farmers are also largely resource poor and therefore cannot afford hired labour. The need for labour is more with improved crop varieties owing to the fact that maize production technologies are labour intensive that could be practiced by household with large household size.

The coefficient of income level was found to be positive $B=0.3285(P \leq 0.05)$ and significantly related to the likelihood of adoption of improved maize varieties in the study area. The result implies that the larger the income of respondents, the greater the probability of adoption of maize production technologies among farmers in the study area. This could be as a result of higher purchasing powers brought about by high income level. With higher income, farmers could procure maize adoption materials. The coefficient of age was found to be positive $B=0.7619(P \leq 0.01)$ and significantly related to the likelihood of improved maize variety adoption in the study area. This implies that older farmers had higher likelihood of adopting improved maize variety compare to the younger ones. This could be as a result of experience gathered by the older farmers. This finding is in contradiction with the a priori expectation which postulated that age has a negative relationship with adoption. It however confirms that older farmers utilize more agricultural information than younger farmers as 
Creative Commons User License: CC BY-NC-ND

Abstracted by: EBSCOhost, Electronic Journals Service (EJS),

Google Scholar, Journal Seek, Scientific Commons,

Food and Agricultural Organization (FAO), CABI and Scopus
Journal of Agricultural Extension

Vol. 24 (1) January, 2020

ISSN(e): 24086851; ISSN(Print); 1119944X

http://journal.aesonnigeria.org

http://www.aiol.info/index.php/iae

Email: editorinchief@aesonnigeria.org

http://eoi.citefactor.org/10.11226/v23i4

found by Bawa that age is related to information utilization because the stage of life of farmers affects their attitude towards information usage.

Results in table 2 reveals that distance to source of technology had positive and significant influence on the likelihood of adoption of improved maize seeds. This implies that farmers who live closer to the source of technology are more likely to adopt the technology and are more likely to use the technology compared to the farmers who live far away from the source of technology. Distance to market had a positive and significant influence on the likelihood of adoption of improved maize varieties among the respondents. These suggested that as the distance to market decreases the rate of use of the maize increases. This could be as a result of reduced difficulties in accessing market by the potential users. The level of household use of improved maize by respondents was found to be positive and significantly influenced their likelihood of adoption of improved maize varieties (Table 2). The result was significant at $1 \%$ of probability. Maize is one of the most important food crops because of its high carbohydrate value. The introduction of improved maize varieties in the study area formed a good step towards improving food security and poverty alleviation

Table 2: Estimate of adoption of improved maize varieties on socio-economic and institutional factors

\begin{tabular}{|c|c|c|c|}
\hline Variable & Coefficient & Std. Err. & $\mathbf{Z}$ \\
\hline Extension contact & 0.0360 & 0.0099 & $3.65^{\star \star \star}$ \\
\hline Sex & 1.8723 & 1.6125 & $1.16 \mathrm{NS}$ \\
\hline Farm size & 0.2319 & 0.0685 & $3.38^{\star \star \star}$ \\
\hline Education Level & 0.0460 & 0.0121 & $3.8^{\star * \star}$ \\
\hline Access to credit & 0.6363 & 0.2751 & $2.31^{* *}$ \\
\hline Household size & 0.2708 & 0.1088 & $2.49^{* *}$ \\
\hline Income Level & 0.3285 & 0.0410 & $8.0^{* \star \star}$ \\
\hline Age & 0.7619 & 0.3137 & $2.43^{* \star}$ \\
\hline $\begin{array}{l}\text { Distance to source of } \\
\text { technology }\end{array}$ & 0.8972 & 0.4125 & $2.18^{* *}$ \\
\hline Distance to market & 0.4131 & 0.1738 & $2.38^{\star \star}$ \\
\hline Utilization of maize & 1.5692 & 0.5478 & $2.86^{\star \star \star}$ \\
\hline Maturity & 0.3342 & 0.0391 & $8.55^{\star \star \star}$ \\
\hline Constant & 0.3562 & 0.0378 & $9.42 * \star *$ \\
\hline
\end{tabular}

${ }^{\star * *} \mathrm{P} \leq 0.01,{ }^{* *} \mathrm{P} \leq 0.05$. Source: Field work 2015

\section{Rate of Adoption of Improved Maize Varieties}

Results in Table 3 depict that Ngabu community has the highest rate of adoption (96\%). This could be due to accessibility to Urban Market and the benefits the community had in terms of extension activities, while Kinging had the lowest adoption rate (63.2\%). This could be attributed to the technological characteristics of the improved maize varieties, such as high yielding, early maturing, striga resistant, high quality flour and high market value. The increase in the rate of adoption is in line with the expectations of the sponsors and implementers of the PROSAB project that introduced the improved maize varieties into the study communities. One of the ideas behind 
Creative Commons User License: CC BY-NC-ND

Abstracted by: EBSCOhost, Electronic Journals Service (EJS),

Google Scholar, Journal Seek, Scientific Commons,

Food and Agricultural Organization (FAO), CABI and Scopus

http://eoi.citefactor.org/10.11226/v23i4
Journal of Agricultural Extension

Vol. 24 (1) January, 2020

ISSN(e): 24086851; ISSN(Print); 1119944 X

http://journal.aesonnigeria.org

http://www.aiol.info/index.php/iae

Email: editorinchief@aesonnigeria.org

introducing improved crop varieties is that adoption of such crop varieties would continue after completion of the project implementation phase.

Table 3: Adoption rate of improved maize varieties

\begin{tabular}{ll}
\hline Community & Percentage (\%) \\
\hline Mirnga & 93.0 \\
Mainahari & 84.0 \\
Tum & 90.5 \\
Jalingo & 85.0 \\
Kinging & 63.2 \\
Kwayabura & 86.0 \\
Wandali & 94.0 \\
Kwayakusar & 95.0 \\
Ngabu & 96.0 \\
\hline
\end{tabular}

\section{Constraints to Adoption of Improved Maize Varieties}

Table 4 shows that about $60 \%$ of the respondents reported non-availability of improved maize seeds as their main constraint. The majority (99\%) of the respondents indicated high cost of improved maize seeds as their constraint, while $88 \%$ of the respondents indicated high cost of labour as a problem in adoption of improved maize varieties. Other constraining factors to adoption of improved maize varieties include striga infestation (52\%) and low market price of output (64\%). The high cost of labour affects production of improved maize by respondents. Maize production is labour intensive; though the majority of the respondents have an average of eight persons in a household, they need additional hired labour. This in turn affects their potential productivity and affects adoption. Without better market price, farmers may be discouraged to sale their products. In addition the high cost of improved seeds will also constrain them from using the improved seeds.

Table 4: Constraints to adoption of improved maize varieties

\begin{tabular}{lcc}
\hline Constraints & Frequency & Percentage $^{\star}(\%)$ \\
\hline Non-Availability of Seed & 151 & 60.4 \\
High Cost of seed & 248 & 99.2 \\
& & \\
High Labour cost & 220 & 88.0 \\
Striga Infestation & 132 & 52.8 \\
Low market price of Output & 160 & 64.0 \\
\hline
\end{tabular}

${ }^{*}$ Multiple response. Source: Field Survey, 2014

\section{Conclusion and Recommendations}

Extension contact, farm size, education level, and age were found to be affecting the adoption of Improved Maize. The adoption rate of improved maize technology as at 2015 was found to improve over the years. It could be as a result of its technological characteristics (Striga resistance, drought and climate change) as well as high yielding trait. High cost of seeds, high cost of labour, and low market prices were found to be the major constraints militating against the adoption of improved maize varieties. 
Creative Commons User License: CC BY-NC-ND

Abstracted by: EBSCOhost, Electronic Journals Service (EJS),

Google Scholar, Journal Seek, Scientific Commons,

Food and Agricultural Organization (FAO), CABI and Scopus

http://eoi.citefactor.org/10.11226/v23i4
Journal of Agricultural Extension

Vol. 24 (1) January, 2020

ISSN(e): 24086851; ISSN(Print); 1119944X

http://journal.aesonnigeria.org

http://www.ajol.info/index.php/jae

Email: editorinchief@aesonnigeria.org

Community Maize seed production should be encouraged and promoted to facilitate easy access to improved seeds by farmers by the subsequent interventions. Also, restrengthening of Community Based Organizations and seed companies to introduce labour saving tools like planters, harvesters etc. by subsequent interventions in the study area.

\section{References}

Ayinde, O.E.; Adewumi, M.O; Olatunji, G.B. and Babalola, O. A (2010). Determinants of Adoption of Downy Mildew Resistant Maize by Small-Scale Farmers in Kwara State, Nigeria

Bawa, D. B. (2011). Analysis of Utilization of Improved Maize Production Technologies among Farmers in Southern Borno, Nigeria. Ph. D. Thesis Department of Agricultural Extension Services, University of Maiduguri. 47-49.

Cavane, E. (2016). Farmers' attitude and adoption of improved maize varieties and chemical fertilizers in Mozambique. Indian Research Journal of Extension Education, 11(21), 1-6.

Doss, C.R., (2013). Understanding Farm-Level Technology Adoption; Lessons Learned from CIMMYT Micro Survey in Eastern Africa, pp 24-35.

Idrisa, Y. L., Ogunbameru, B. O. and Amaza, P. S. (2010). Influence of Farmers Socio- economic and Technology Characteristics on Soybean Seed Technology Adoption in Southern Borno State, Nigeria. African Journal of Agricultural Research, 5(11): 34-37

Idrisa,Y.L.,Ogunbamerun,B.O and Shehu, H. (2012) Effect of adoption improved maize seed on household food security in Gwoza Local Government area of Borno state, Nigeria. Agricultural Science Research Journals Vol.2(2)pp.70-75

Kamara, A.Y., N. Kamai, F. Kanampiu, L. Kamsang, A.Y. Kamara (2018). Gender analysis of soybean adoption and impact. IITA, Ibadan, Nigeria. 57pp

National Bureau of Statistics Nigeria (NBSN). (2010). Nigeria poverty profile 2010. Retrieved on 15 August 2016 from: http://www. nigerianstat.gov.ng/pdfuploads/Nigeria\%20Poverty\%20Profile\% 202010.pdf

National Population Commission (NPC) (2006). Nigerian Population Commission, Abuja. Population of Nigeria by State and Sex, 1991 and 2006. 